\title{
Culinary identity as the determinant of cultural distinctiveness in Silesia and the Vilnius region
}

\author{
Waldemar Żarski
}

\begin{abstract}
The article focuses on two basic questions: the problem of ethnic and cultural identity, and the linguistic and cultural interpretation of the culinary semantic scene. The analysis includes various ways of how the Silesian and the Vilnius region cuisines have been perceived in Poland in the $19^{\text {th }}$ and $20^{\text {th }}$ centuries. Particular attention has been paid to the most important determinants of culinary identity seen as distinct components of the Silesian and Vilnius region cultural communities. The author's conclusion is that culinary tradition functions as a theoretical structure established in ethnic, cultural and social consciousness rather than in the real experience of a regional or national cuisine.
\end{abstract}

Keywords: culinary identity, Silesia, Vilnius region, Polish cuisine

Issues embedded in this article focus around the concept of culinary identity perceived as one of the main components of ethno-cultural distinctiveness of two geographically remote ethno-cultural communities, namely Silesia and the Vilnius region. The subject of the present analysis is the cultural and linguistic perception of Silesian and the Vilnius region cuisine; we will discuss the question whether national and regional cuisines really exist or if they are only theoretical constructs stereotypically interpreted and solidified in a sense of awareness of a particular social group. Showing how most significant elements of culinary identity function as elements of cultural distinctiveness of Silesian and the Vilnius region borderland community is the objective of this work. We will pay attention to most frequent and most typical factors that contribute to the prototypical effect of the aforementioned issue.

Dating back to the beginnings of mankind, human nourishment, deeply rooted in culture and tradition, has carried a strong community aspect. Therefore the cultural concept of "food" does not consist of all possible nourishing elements but only of these that are considered to be food by the members of 
a given community. There has to be a common agreement about the ways of preparing food and its consumption. The abovementioned ways become rules and modi operandi, the identification criteria of a particular ethno-cultural community. Ways of making, storing and consuming one's own food are the result of particular historical, socio-cultural and axiological processes, the essence of which is in creating, maintaining and ensuring the conditions needed for the development of social communities. Such behaviour is defined as a culinary act - i.e. a conscious choice, evolving as the consequence of an evolution of perceptive, ethical and aesthetic norms and behavioural patterns of a given community. It is based on two concepts: a kitchen and a dining room, frequently defined through hypernyms: gastronomy and culinary art. Both lexical entries are perceived from two perspectives: preparing the food and consuming it. It is clearly seen in culinarius - the Latin adjective for 'culinary' ('kitchen' - attributive), being a derivative of culina - the noun, meaning 'cuisine / food', and gastronomia - the Greek noun motivated by the word gaster, meaning 'belly / stomach'. Gastronomy is most frequently perceived as culinary art - the art of preparing food which is based on professional knowledge (Halbański 1983; Michalik \& Łebkowski 1996). Marta Norkowska, in her book from 1904, has proposed the most complete definition:

It is the art of preparing and applying nourishment, - the ability of choosing nourishing substances, namely products, - the art of distinguishing their advantages and disadvantages, including harmful sides - finally, there is the mystery of studying and being acquainted with transformations that all the dishes have to go through; skilful and reasonable flavouring of dishes with various spices and aromas - fragrances that result in a pleasant taste, satisfying the relevant hygiene requirements, being suitable for maintaining health, and looking wholesome on a permanent basis [translations here and below by the present author].

A century ago, eating and other nutrition-related behaviours appeared rarely as a subject of scientific research. The topic had been considered as trivial and perceived as having very little in common with science until the mid- $20^{\text {th }}$ century. Roland Barthes (1997: 21) rightly commented on such approach in the following way: "we do not notice our own food, or, what is worse, we assume that it is insignificant". The increase of interest in culinary issues became observable in the 1960s as cultural anthropologists, first of all Claude Lévi-Strauss, Mary Douglas, Norbert Elias and Pierre Bourdieu, started to work with the subject. As far as culinary research in Poland was concerned, archaeological, ethnographic and historical studies prevailed. Recently published monographs 
fill in the bibliographic gap (see Kowalski 1998; Eichstaedt 2000; Stegner 2003; Straczuk 2006; Żarski 2008).

The majority of researchers investigating the history of national cuisines do not view the object of their study as homogeneous. There have always been differences in time, region, class, religion and customs. Basically, these resulted from different social status, the way people behaved at the table, the types of ingredients used, and the way of combining them. The history of mankind and its culture is closely connected with changes related to ways of eating. Behavioural patterns at the table are the source of knowledge and can be helpful in understanding diversity among nations. Culinary identity connects material and spiritual spheres that determine cultural, social, mental and economic perspectives perceived both diachronically and synchronically. The culinary code is among the most long-lasting exponents of a group and its social and national identity patterns. The consept of the borderland cuisine is complex; it results from the type of social awareness in which historical reality in individual and group reception takes on a different dimension. Opinions about the given cuisine and the table are generally diversified. For example, emigrants tend to mythologise family and ethnic cuisine most frequently. Identity and ethnocultural issues play the key role in research about the Eastern borderlands of Poland. The subject matter oscillates around linguistic and religious identity of the members of these communities. The issues are connected with national identity on the one hand, and focusing on the products of culture on the other hand. But all of them usually aim at validating previously made assumptions than making new ones.

The borderland is frequently described as a set of peripheral geographical areas that are not in direct contact with each other. The term 'borderland culture' treated as a collection of features of different origin and forming a functional unity appears to be more accurate than the notion of multiculturalism. Neighbourhood - an area of everyday contacts among people who share a system of communication in the framework of co-created culture - becomes the key term. Social and cultural specificity of culinary traditions has been described with reference to Silesia (Ślq̨sk), the Masuria region (Mazury), Polesie and the Vilnius region (Wileńszczyzna).

The role of food in shaping borderland multiculturalism and culinary identity is the basic issue in this article. The type of food, ways of serving it, the structure and function of convivial gatherings in relation to cultural preferences and social situations are relevant in determining the characteristics of ethnic identity. Nutrition rules become the tool of social inclusion and exclusion; they 
delimit clear borders among groups and nations. Culinary customs contribute to the emergence and functioning of national stereotypes and give rise to such ethnic slurs as makaroniarze ('macaroni', 'spaghetti-eaters') or żabojady ('frogeaters', 'froggies'). National cuisine does not have to reflect the reality and the process of shaping it is correlated with shaping national identity. Apart from the commercialisation of national culinary preferences, there is an important sphere of customs and inclinations which stem from the habits experienced in childhood. Family customs wholly determine one's culinary tradition, and through being such emotionally loaded concepts, they lay memory-based foundations to the culinary behaviour in later life.

Identity is among the basic socio-cultural notions. It has become a key term and defining category that registers all possible cultural, social, economic and political changes. The sum of changing identities is active in the process whereby social reality influences the individual to choose the social roles. The broadest definition of identity describes this process as becoming aware of the self in all aspects of being and acting, setting the common and distinctive features of the self in relation to other members of the same identification group(s). Identity is a complex and changeable phenomenon, a multidimensional construct linking personal elements of the system with the main cultural values of the group to which a given individual belongs. Searching for new ways of determining one's uniqueness and individuality on the micro- and macro-group level is the natural reaction to increasing globalisation. In this vein, the homogenised popular culture of fast-food restaurants leads to the unification of cultural identity and the disappearance of its local exponents: flavours, tastes, colours and the essentials of table etiquette (on globalisation, see also Lubecka 2013, this volume).

It is the kitchen that is the most symbolic interaction space between the house and the nature. The transformation of products from the nature into products of culture occurs there which requires being skilful in cooking and preparing food. This skill materialises in the kitchen. The kitchen, similarly as the garden, generates specific mechanisms of sociability and conviviality which are particular manifestations of a feeling of being at home. First of all, home has an emotional potential evoked by the perception or sensations rooted in memory. Spatial concentration, occupying a strictly specified territory, is not only the symbol of every ethnic community but, even more vividly, a specific type of bond between people who share an affinity for ideas, values and common identity symbols. Stanisław Vincenz characterising the life of butynars in the novel "Zwada" (“The Quarrel”), writes:

Every mouthful of their dishes place them in their cottages, in their homely surroundings. They led a tough life and existed in poorer conditions than at their place - in the cottage, but every mouthful strenghtened their 
conviction that their life is the same, as their ancestors' life hundreds of years ago or even earlier - without any mention of exile (1981: 144-145).

As far as describing the multinational borderland is concerned, the opposition between "us" and "strangers/foreigners" becomes an important issue, evident in the syncretic borderland cuisine. This has been described by Melchior Wańkowicz in his nostalgic work "Szczenięce lata" ("The early years") (1974: 17-18), where he describes the dishes of two tables - one belonging to the servants and the other to landlords. He describes in detail how the butler and servants "used to eat abraduki - dumplings made of thick flour in pork fat; skrzydle ('wings') - pancakes made of the same flour with fat dripping from it, hard as leather; szpekuchy - dumplings, the thin crust of which was puffed out by hot pork fat ${ }^{1}$; szwilpiki - pancakes made of boiled potatoes, roasted in a stove; kekory - the similar pancakes stuffed with various meat, vegetable and cheese fillings [...]. Kindziuk or skittądź - a pork stomach filled with meat and off-cuts, seasoned with nitre and spices, sometimes also smoked, prepared for servants right before winter. These delicacies appearing on 'the servants table' were taken over by the first table as a snack for enthusiasts. The first table was fat, rich and heavy but apart from kotduny ${ }^{2}$, cucumbers with honey, jelly/fruit cream and several other delicacies, the landlords ate common dishes known around in the world.

Culinary distinctiveness is even more vividly perceived in memories from the childhood, youth, and places that had to be left soon and forever. People often go back in their minds to a safe home and happy family. It can be observed in quite an atypical cook-book by Barbara Hołub (1992), in which recipes form the background to the author's interviews with the citizens of Vilnius and its surrounding areas, who are simultaneously representatives of typically Polish culture. This is how the author justifies her idea:

Recipes from the Vilnius region were collected in the book. It is important to note that these were Vilnius recipes - not those knowv in the entire Vilnius region. They are not the same! These dishes are characteristic of Vilnius. This is the reason why there are so many dishes based on potatoes and the good Vilnius sourcream. There are many dishes which are hard to find elsewhere - they were handed down from generation to generation, known only in a few settlements and out-of-the-way localities. [...] Apart from the recipes provided by female Vilnius housekeepers, I collected recipes found in old calendars, farm handbooks and cook books (Hołub 1992: 7).

1 Stuffed with lard and fried onion; a traditional Easter dish of Polish families in Lithuania; the dish is of German origin - here and elsewhere, author's annotation.

2 Stuffed dumplings made of unleavened dough, usually filled with meat and mushrooms. 
The interviews conducted by Barbara Hołub were most frequently about the relations between the Vilnius cuisine and Vilnius customs. People told her: "I will always remember buckwheat bliny ${ }^{3}$ that my mother baked; the taste of Easter ham or memories of grey/blue dusk outside the window when we were about to sit at the Christmas Eve table [...] And I regret them most" (Czesław Niemen). "All the products from the Vilnius region tasted differently. Oh, Lord, what meat and sausage was produced there! It is a long story about our Vilnius ham or about the cream that was used in many dishes in the region. For example: bliny with thick cream - can there be anything better than that?" (Marian Podkowiński). "You could eat rich and tasteful dishes there. The Vilnius cuisine was known for that. There were fatty dishes, but they were so prepared that this was kept as a sweet memory and not put in doubt" (Zygmunt Kęstowicz).

A bit longer commentary to the cultural motivation of culinary customs in Vilnius is presented by Polish writer Tadeusz Konwicki in his book "Sennik współczesny” (“A dreambook for our time”) (1970):

Surely you know bliny as a national Russian dish. I, as a self-taught gastronome, consider bliny as the dish of the Grand Duchy of Lithuania. I assume that this delicacy came from Lithuania to Russia. How did that happen? There was a constant flow there. In earlier times, people were moving through borders and despite borders. Skowronska, the wife of Peter I, might haved played her role in the exchange of experience and culinary customs. [...] Bliny was the basic dish in the Vilnius region whereas bread plays the same role in Poland. Bliny were essential in the Vilnius region. [Buckwheat bliny - author's comment] are not our Vilnius bliny, however they were known and eaten in the Vilnius region. But they were not, so to say, of our origin. [...] One used to eat black pudding. But not the one as in here, not such a monotonous dish. There was the whole universe of black puddings ...something delicious. [...] When one talks about the Vilnius Christmas Eve, everyone immediately mentions kutia4. And I didn't eat kutia. There wasn't any kutia in my neighbourhood. I think that this dish is more of a Southern origin, rather from Ukraine than from the Vilnius region. True Vilnius citizens - the same as I used to eat podsyca with śliżyki ${ }^{5}$ [with spoon - author's annotation] [...] I think that writing a book about the cuisine, customs and the philosophy of the table is a kind of longing for something stable and long-lasting in our identity (Konwicki 1970).

3 Pancakes made from buckwheat flour and served with sour cream.

${ }^{4}$ Sweet grain pudding traditionally consisting of wheatberries, poppy seeds and honey.

5 The former - Christmas Eve yeast rolls served with poppy milk; the latter consisting of poppy, honey, almonds and milk; usually served in a bow. 
As far as the eating habits of the Silesian inhabitants in the Middle Ages and the Renaissance are concerned, information comes from the descriptions of ducal feasts and just a few written sources of middle-class culinary recipes from the second half of the $13^{\text {th }}$ century. Sources grow in size when domestic calendars started to spread as well as diaries from journeys started being written in which menus and descriptions of convivial gatherings were published. There were not many instances of culinary topics in the $19^{\text {th }}$ century press. Cookbooks and culinary handbooks were primarily found in houses.

Porridges, especially millet porridge but also porridge made of barley (using boiled water, butter and salt) were everyday dishes for the Silesians. Farm servants usually ate three meals a day - breakfast, dinner and supper. Basic boiled meals comprised of barley, buckwheat and rye groats. When it comes to the dishes of poorer inhabitants, they ate roasted dumplings made of barley flour, but also milk soup and peas. Cabbage played a significant role, especially when boiled with pork meat or eaten as sauerkraut. It provided natural supplement of fat, protein and carbohydrates. Fruit and vegetable soups were cooked and eaten during summer, together with bread without butter. The so-called black bread was most frequently consumed among the poor; the rich ate white bread. Twists and cakes were baked with butter and yeast but without eggs, therefore the dough was well-risen, not spongy. Lucjan Malinowski valued the Silesian cuisine very high in his "Zarysy życia ludowego na Szląsku" ("An outline of the folk life in Silesia"):

The food of inhabitants of Silesia is rich and healthy. Here is the Silesian diet: they drink coffee with milk and eat bread with butter for breakfast. Coffee is not a luxury drink there; it is drunk commonly, even by servants and wenches. Dinner served around one o'clock in the afternoon consists of soup, meat and lettuce or sour milk with potatoes and meat. They eat from one bowl, the host with his family and servants together. The afternoon snack is around 4 o'clock in the afternoon and consists of bread with butter and delicious cheese. The evening ensures warm supper. Bread is white everywhere, I didn't see black wholegrain bread anywhere in Silesia (Wawoczny 2005: 218).

Polish and German sources from the $19^{\text {th }}$ century and later describe the Silesian cuisine as fat, rich and filling. It is still a distinctive spot on the culinary map of Poland due to its character and taste most frequently connected with dishes like roulade, dumplings and red cabbage. It was based on self-sufficiency - the food products came from local farms. It was an austere, though often a monotonous 
cuisine. The same dishes were frequently eaten during the day and even through the whole week. Vegetables and dairy products prevailed, whereas dishes containing meat were prepared solely on feasts or important family celebrations. Differences between villages and towns in the way of eating disappear as early as in the $20^{\text {th }}$ century. Traditional menu becomes then supplemented with new dishes from urban and even international cuisine. Due to migration, all this resulted in the mixture of culinary customs of various backgrounds and regions. In spite of that, the attachment to tradition based on ancestors' wisdom passed from generation to generation is still clearly seen in Silesia.

Culinary tradition and its socio-cultural function is, together with dialect, one of characteristic identity-bound features of the Silesia region. Soups eaten during breakfasts were common. $\dot{Z} u r$ (a type of sour rye soup; sometimes called 'żurek'), wodzionka (a type of bread soup frequently misspelled as 'wodzianka'), zacierki with pork fat (a type of chopped and grated dumplings) and owsianka (a type of oatmeal porridge) were the most favourite dishes. The demand for $\dot{z} u r$ increased the most during the Lent. The preparation of $\dot{z} u r$ for Lent was based on the special sourdough out of $1 \mathrm{~L}$ of water, 20 decagrams of wholemeal wheat flour, a clove of garlic, and a crust of black wholegrain bread. During weekdays, karbinadle (minced pork meat cutlets) made of beef-pork or only pork meat were served, alongside with golonka (knuckles of pork) with cabbage and peas, ptucka (lights/lungs) in a sour stew, beef heart stew, stewed sauerkraut and krupnioki (a type of blood sausage/black pudding) fried with onion. Fish was served on Fridays - most frequently cods, trouts and herrings.

Stuffed dumplings, gotabki (stuffed cabbage leaves) or krokiety (boulette) are very rare on Silesian tables. The contemporary Silesian cannot imagine his or her feast table without beef roulade, gravy, Silesian dumplings and red cabbage. These are usually served after soup with noodles or chicken soup with pasta. Beef roulade is served with Silesian dumplings, made of boiled potatoes and potato flour, which became popular before the Second World War. Sundays and other celebration days presented occasions to eat more delicacies. Friday evening was the starting point for preparing the food, namely for baking cakes. For breakfast, boiled frankfurter sausages or home sausages with bread, butter and mustard were usually eaten. Natural coffee was served in houses of affluent people, whereas poorer ones drank ersatz coffee. Chicken soup with pasta/spaghetti or the so called 'runny dough' was a popular first course for the dinner; the second dish consisted of roulade with white or black dumplings and red cabbage. Roasted duck, chicken, schab sztygarski (mine foreman's pork loin), pieczeń huzarska (hussar roast meat) or roasted rabbit were also eaten. Green lettuce, sauerkraut or cucumber salad was added to the main dish. 
Christmas Eve Supper required festive and savoury culinary setting. Peas, sweet almond or mushroom soups were most frequently served first. Gałuszki (cutlets made of meat and potatoes) and dried fruits were added to the mushroom soup. Roasted carp was customarily the main dish, after which makówka resembling kutia was served; also moczka (Christmas Eve dish made of fruits, gingerbread, nuts, raisins and dark beer) was on the menu. Siemieniotka (a type of soup made of hemp seeds) was another sweet delicacy that is still prepared until nowadays. It is cooked by pouring boiling water on hemp seeds, then filtering and whipping the hemp seeds in a stępa (a type of mortar) until the hemp seeds are removed. Water and milk is then squeezed out of the seeds which are boiled with added flour. One can also add some salt and sugar.

Another tradition was created by miners. A rich, fat dinner in a miner's family was just a meal and at the same time a kind of reward for the discomfort and the toil of mining work. Miners' breakfast consisted of milk or ersatz coffee and krupnica (thick ground wheat) with pork fat or butter being added in winter. Vegetable soup, wodzionka or milk soup was prepared for dinner, as well as cabbage with potatoes and meat dishes. Miners' traditional food was krupnioki - pork intestines stuffed with groats and barley porridge mixed with animals' blood.

The culinary tradition of Lower Silesia and Wrocław, its capital, was completely different; an emergence of a transformed identity and new culinary tradition after the Second World War was tied, first of all, to the immigration from various other regions of Poland, mainly from the Eastern borderlands. According to Grzegorz Sobel (2006), despite the fact that Wrocław did not hold an eminent position in culinary annals, encyclopaedias and lexicons, and just a few dishes can be associated with this city, it would be a mistake to claim that the city had nothing to offer from the culinary point of view. Wrocław's culinary scene in the 1920s is known thanks to an anonymous Dresden inhabitant:

It is completely different at your place! Even though there is no artistic fever in your museums and your treasures of culture are not impressive at all, you do have 'Piwnica Świdnicka'6 and other famous pubs instead, and tourists who come to you eat, drink and do sightseeing, look at shops' windows and buy things. We, Dresden people, envy you for that. Wroctaw is brimming with life, the movement is observable everywhere in the city; your wine bars, pubs and coffee bars are always full of people (Sobel 2006: 6).

$\overline{6}$ Świdnicka Cellar - the oldest restaurant in Europe. 
Dumplings (based on flour, bread and finally on potatoes) were eagerly eaten and their presence showed the special character of Wrocław cuisine. They were served with pork cracklings (well fried, small pieces of lard), gravy or butter, and were an indispensable addition to meat in every form. Apart from beer being the symbol of Wrocław across the whole territory of Prussia, sausage was sold in booths at the Central Market. Garlic sausage and dry sausage known among Germans as Knackwurst were highly valued also abroad. In fact Wrocław cuisine had its contribution to shaping the Silesian culinary habits. Frequent family, social, commercial, professional and cultural contacts led to the development of a mixture of traditions and broadened the idea of culinary identity. A growing role was gradually attached to the impact of the Czech, Jewish, Russian and Hungarian traditions, apart from Polish and German influences. At the turn of the $19^{\text {th }}$ century, Wrocław inhabitants got to know tastes of the French, Italian and Spanish dishes. The Silesian cuisine, similarly to other regional cuisines, underwent deformation, whereby its distinctiveness and local taste became weaker. Typical dishes were prepared more and more frequently only on special occasions. The process of their ritualisation and emotionalisation began in this period. Old dishes became stowed as a part of the culinary heritage and played a smaller role in the everyday rhythm of the culture.

The only Wrocław and Silesian delicacy, apart from Schlesische Streuselkuchen (yeast dough with cinnamon crumble) that was noticed and noted down in German cookbooks, is Schlesisches Himmelreich; roasted pork meat served with dumplings and stewed fruits. The aforementioned cake with crumble is another delicacy that was even favoured by Prussian Hohenzollerns. It was regularly present in middle-class houses accompanying Sunday coffee or tea, and was baked according to the following recipe:

Prepare barm dough as for regular baking, but without raisins and almonds - add a few eggs more instead. Make crumble out of 120 grams of sugar covered with 375 grams of melted butter and give as much flour as the whole mass takes. Add some vanilla and a solid pinch of cinnamon so that the smell should be an intensive one. Sprinkle the dough with already formed clods and bake it one hour long in a well-heated stove (Sobel 2006: 153).

Marek Krajewski is one of the people who showed the experience of the real culinary atmosphere of Wrocław, or the Prussian Breslau, in a very suggestive way in his novel about Eberhard Mock, the legal advisor. The hero of his novel usually started his day with scrambled eggs with chanterelle mushrooms. If 
he was lucky he did not spurn the apple twist and the cup of coffee. Due to the concentration of duties and lack of time, he used to eat his dinners in one of the bars close to the Police Presiding Board Building. He was a great fish gourmet, and often ordered eel covered with fennel dressing with slightly fried onion or cod in a mustard butter. He did not refuse meat either, which is why slices of duck's breast or mutton with herbs were present on his table. He also used to order military bread with spicy chopped meat in Pod Zielonym Polakiem ('Under the Green Pole Inn'). Piwnica Biskupia ('Bishop's Cellar') was his most favourite culinary place where he used to eat pike-perches with turnip salad and drink beer from 1 litre beer mug. He also liked roasted pork with white cabbage served thick with dumplings and pork crackles.

As already noted, the culinary identity of Silesia changed after the Second World War. This happened especially in places populated with Poles who were forced to leave their dwellings in the East due to border changes after the Yalta Conference. Representatives of various traditions and culinary customs, as well as people with diverse ethno-cultural identities, began to co-exist next to each other. New dishes, new customs and new cultural patterns entered the Silesian cuisine. Tomasz Różycki rightly showed the new kitchen and table customs in his poetic mock-heroic work "Dwanaście stacji" ("Twelve stations"), locating its plot in the contemporary Opole. In a very subtle way, he unveils a relatively recent past full of humour, nostalgia and irony, and confronts it with the absurd and grotesque presence of the colourful traditions where the Silesian everyday life is mixed with German and Eastern borderlands culture. One of the 'stations' is devoted to stuffed dumplings, and the description of its preparation and taste can easily compete with Adam Mickiewicz's overview of boiling bigos (a sauerkraut stew) in the novel "Pan Tadeusz". The author gives a profound cultural analysis of this trivial dish, which was relatively foreign to the Silesians in earlier generations. Różycki takes into account the most significant factors that decide the cultural function of stuffed dumplings and their ritual meaning in the Polish culinary tradition.

The notion of home, being the place of comfort, safety, peace and lightheartedness, plays the key role in the interpretation of ethno-cultural identity that also comprises culinary distinctiveness. The kitchen - the most symbolic space of interaction between the home and nature - creates a sense of conviviality and simultaneously generates a specific emotional potential. This aspect of creating of the Silesian culinary identity against a broad cultural context is powerfully highlighted by Wera Sztabowa (1985):

7 One of the greatest masterpieces of Polish literature and national epic, set in a fictional village of Soplicowo in the former Grand Duchy of Lithuania. 
I was told: The Silesian cuisine? But it does not exist! However, a mental picture of my grandmother's kitchen was persistently returning to me: a huge cupboard occupying almost half of the kitchen, decorated with paper laces, thick delft-ware plates with a blue floral pattern, buncloki [pots] put on the bench in different rows, kwyrdloki ${ }^{8}$ hanging over the stove and a sentence carefully embroidered by auntie Anna on a snow-white starched hanger stating: 'Early to bed and early to rise makes a man healthy, wealthy and wise'. [...]. Other girls were giving their dolls a ride using toy prams around the housing estate by-lanes and I was sitting on a kitchen stool and observing my grandmother: how she mixes the dough for little Polish wheel cakes, puts slices of bacon on meat and spreads mustard in a bountiful manner and then ties oblong roulade up with a white thread, how she grinds potatoes to make black dumplings and chops red cabbage for deep blue szałot [Silesian vegetable salad]. Real culinary excitement used to begin soon before Christmas, though. The whole house was full of ginger-like scents: anise, cinnamon, vanilla, coriander, clove and ginger. Fish were in a bath-tube and poppy was frying with honey in the saucepan - it was for makówki and moczka was boiling as well. It is quite hard to describe the Silesian cuisine as a homogenous gastronomic system due to the fact that culinary influences from various sides mixed there: Slavonic, German, Austrian, Czech, Italian and even Turkish. They all had quite a big influence on the Silesian cuisine. It does not mean, however, that Silesian recipes do not exist. They appear quite often and dishes prepared on the basis of these recipes are fancied by everyone who has tried them at least once. [...] If I were to describe any ordinary but festive occasion in a Silesian family, I would point at the Sunday dinner. It has its own ritual and is prepared with great reverence: a white tablecloth on the table, flowers, better tableware. And the atmosphere. This unique atmosphere of family unity (Sztabowa 1985: 5-6).

The atmosphere of preparing food perceived in the broadest cultural context is the determining factor referring to the characteristics of regional cuisine and its culinary identity - both in the Vilnius region and in Silesia. The multifaceted character of food is definitely one of the cultural exponents of lifestyle. An analysis of social gathering issues requires an even more extensive anthropological reflection set in an intercultural context. Our tastes and the way we

8 In general Polish known as mątewka; optionally known as kwyrlok, fyrlok or rogolki (in plural) in Silesia, firlajek in Łódź and kwirlejka in Poznań; a wooden kitchen tool used to mix uncooked dough. 
estimate them are determined by cultural patterns emerging from a long and rich culinary tradition.

\section{References}

Barthes, Roland 1997. Toward a psychosociology of contemporary food consumption. In: C. Counihan \& P. Van Esterik (eds.) Food and culture. New York-London: Routledge, pp. 20-27.

Eichstaedt, Jarosław (ed.) 2000. Smak biesiady. [The taste of convivial gathering.] Ożarów: Towarzystwo Przyjaciół Muzeum Wnętrz Dworskich.

Halbański, Maciej 1983. Leksykon sztuki kulinarnej. [Lexicon of culinary art.] Warszawa: Watra.

Hołub, Barbara 1992. Przy wileńskim stole. [At the Vilnius table.] Białystok: Książka I Wiedza.

Konwicki, Tadeusz 1970. Sennik wspótczesny. [A dreambook for our time.] Warszawa: Czytelnik.

Kowalski, Piotr (ed.) 1998. Oczywisty urok biesiadowania. [The obvious charm of convivial gatherings.] Wrocław: Towarzystwo Przyjaciół Polonistyki Wrocławskiej.

Lubecka, Anna 2013. Polish ritual year - a reflection of Polish cultural policy. In: L. Laineste \& D. Brzozowska \& W. Chłopicki (eds.) Estonia and Poland: Creativity and tradition in cultural communication, Vol. 2: Perspectives on national and regional identity. Tartu: ELM Scholarly Press, pp. 83-98.

Michalik, Małgorzata \& Łebkowski, Marek 1996. Mała encyklopedia sztuki kulinarnej. [A small encyclopedia of culinary art.] Warszawa: Tenten.

Norkowska, Marta 1904. Najnowsza kuchnia wytworna i gospodarska. [The latest cuisine: refined and economical.] Warszawa: Gebethner i Wolff.

Sobel, Grzegorz 2006. Przy wroctawskim stole. [At the Wrocław table.] Wrocław: Wydawnictwo Dolnośląskie.

Stegner, Tadeusz (ed.) 2003. W kuchni $i$ za stotem. [In the kitchen and at the table.] Gdańsk: Granit.

Straczuk, Justyna 2006. Cmentarz $i$ stót. [The cemetery and the table.] Wrocław: Wydawnictwo Uniwersytetu Wrocławskiego.

Sztabowa, Wera1985. Krupnioki i moczka, czyli gawędy o kuchni śląskiej. [Chats about Silesian cuisine.] Katowice: Śląsk.

Vincenz, Stanisław 1981. Na wysokiej połoninie. Nowe czasy: Zwada. [On high pastures. New times: The Quarrel.] Warszawa: Pax.

Wańkowicz, Melchior 1974. Szczenięce lata. [The early years.] Kraków: Pax. 


\section{Waldemar Żarski}

Wawoczny, Grzegorz 2005. Kuchnia raciborska. [Racibórz cuisine.] Racibórz: Wydawnictwo i Agencja Informacyjna WAW Grzegorz Wawoczny.

Żarski, Waldemar 2008. Książk kucharska jako tekst. [The cookbook as a text.] Wrocław: Wydawnictwo Uniwersytetu Wrocławskiego. 